\author{
dr Paweł FOLFAS \\ Kolegium Gospodarki Światowej, Szkoła Główna Handlowa w Warszawie \\ e-mail: pawel.folfas@sgh.waw.pl
}

DOI: $10.15290 /$ ose.2016.06.84.02

\title{
EFEKT FORRESTERA W MIĘDZYNARODOWYM HANDLU DOBRAMI FINALNYMI I DOBRAMI POŚREDNIMI
}

\begin{abstract}
Streszczenie
Zjawisko polegające na wzmocnieniu reakcji etapów produkcji należących do górnej części łańcucha dostaw na zmiany popytu w jego dolnej części (u nabywców finalnych) nosi nazwę efektu Forrestera. W rezultacie wartości handlu dobrami pośrednimi podczas kryzysu maleją bardziej (odpowiednio: rosną bardziej podczas ożywienia gospodarczego) niż wartości handlu produktami finalnymi. Celem opracowania jest weryfikacja występowania efektu Forrestera w handlu międzynarodowym państw wysoko rozwiniętych w latach 2008-2011. W tych latach w państwach wysoko rozwiniętych wartości eksportu i importu dóbr pośrednich wahały się w większym stopniu (w kategoriach bezwzględnych i względnych) niż wartości eksportu i importu dóbr finalnych i to niezależnie od przyjętej metody mierzenia handlu międzynarodowego (badanie empiryczne zawarte w tym opracowaniu opiera się na dwóch sposobach mierzenia handlu - za pomocą międzynarodowej tablicy przepływów międzygałęziowych oraz nomenklatury BEC). Dowodzi to występowania efektu Forrestera w handlu międzynarodowym oboma rodzajami dóbr w badanym okresie.
\end{abstract}

Słowa kluczowe: efekt Forrestera, handel międzynarodowy, dobra finalne, dobra pośrednie

\section{FORRESTER EFFECT IN INTERNATIONAL TRADE IN FINAL GOODS AND INTERMEDIARIES}

\begin{abstract}
Summary
Forrester (bullwhip) effect refers to increasing swings in inventory in response to shifts in customer demand as one moves further up the supply chain. As a result, the values of international trade in intermediaries fluctuate more strongly than those of international trade in final goods. This paper is an attempt to confirm the existence of Forrester effect in international trade of developed countries in years 2008-2011. Empirical studies based on statistics from world input-output tables as well as trade statistics according to the BEC nomenclature confirm that in developed economies between 2008 and 2011, the values of international trade in intermediaries fluctuated more strongly than trade in final goods. It proves the existence of Forrester effect in international trade in final goods and intermediaries in this period.
\end{abstract}

Key words: Forrester effect, international trade, final goods, intermediaries

JEL: F14 


\section{Wstęp}

Zjawisko polegające na wzmocnieniu reakcji etapów produkcji należących do górnej części łańcucha dostaw na zmiany popytu w jego dolnej części (u nabywców finalnych) nosi nazwę efektu Forrestera. W konsekwencji np. kilkuprocentowy spadek (wzrost) popytu detalistów przekłada się na kilkunastoprocentowy spadek (wzrost) produkcji dóbr pośrednich. Główną przyczyną występowania efektu Forrestera jest sposób zarządzania zapasami. W okresie kryzysu gospodarczego wytwórcy nie tylko redukuja produkcję finalną, lecz również dostosowuja zapasy do zmniejszonej wielkości zamówienia, dlatego zamawiają mniej dóbr pośrednich niż zazwyczaj - efekt Forrestera jest tym silniejszy, im dłuższy jest łańcuch dostaw. W rezultacie wartości handlu dobrami pośrednimi podczas kryzysu maleją bardziej (odpowiednio: rosną bardziej podczas ożywienia gospodarczego) niż wartości handlu produktami finalnymi [Forrester, 1961]. Efekt Forrestera może być złagodzony przez: poprawę przepływu informacji w łańcuchu dostaw, ograniczenie opóźnień w dostawach, a także lepsze prognozowanie zmian wielkości popytu na dobra finalne.

Celem opracowania jest weryfikacja występowania efektu Forrestera w handlu międzynarodowym w latach 2008-2011. Rok 2008 to symboliczny początek ostatniego światowego kryzysu gospodarczego i ostatni rok przed dużymi spadkami wartości produkcji i handlu międzynarodowego, które miały miejsce w 2009 roku. Okres 2010-2011 to kolejne lata kryzysu gospodarczego, podczas których jednak wartości handlu międzynarodowego przeważnie wzrastały. Rok 2011 jest ostatnim rokiem badania, z racji braku danych (brak międzynarodowych tablic przepływów międzygałęziowych) za rok 2012 i kolejne lata.

Próba badawcza składa się z 38 wysoko rozwiniętych gospodarek - 28 państw członkowskich Unii Europejskiej (w badaniu są traktowane one łącznie jako UE-28; dane dla UE-28 obejmują jednak handel między państwami członkowskimi), państw członkowskich EFTA (z wyjątkiem Księstwa Liechtensteinu), USA, Kanady, Australii, Nowej Zelandii, Japonii, Korei Południowej i Izraela. Ze względu na brak dostępu do międzynarodowej tablicy przepływów międzygałęziowych dla większości państw rozwijających się, próbę badawczą ograniczono do państw wysoko rozwiniętych.

Przedmiotem badania jest natomiast eksport oraz import dóbr finalnych i dóbr pośrednich mierzonych na dwa sposoby $-\mathrm{z}$ wykorzystaniem międzynarodowej tablicy przepływów międzygałęziowych i z użyciem nomenklatury BEC (Broad Economic Categories). W rezultacie opracowanie zawiera również charakterystykę szeregu niuansów związanych z mierzeniem handlu międzynarodowego.

Artykuł składa się z trzech zasadniczych części. Pierwsza zawiera przegląd wybranych opracowań weryfikujących występowanie efektu Forrestera. Druga dotyczy handlu międzynarodowego dobrami pośrednimi i finalnymi, mierzonego za pomocą międzynarodowej tablicy przepływów międzygałęziowych, zaś trzecia jest poświęcona eksportowi oraz importowi dóbr finalnych i pośrednich, których wartości są szacowane dzięki zastosowaniu nomenklatury BEC. 


\section{Przegląd literatury i metoda badawcza}

Badanie empiryczne zawarte w tym artykule stanowi kontynuację badania przeprowadzonego wspólnie z Czarny i Śledziewską na temat międzynarodowego handlu dobrami finalnymi i dobrami pośrednimi. W tamtym badaniu, wykorzystując grawitacyjne modele handlu, wykazano, że załamanie handlu międzynarodowego w 2009 roku o wiele mocniej dotknęło handel dobrami pośrednimi niż handel dobrami finalnymi. Tym samym dokonano weryfikacji efektu Forrestera [Czarny, Folfas, Śledziewska, 2012].

Niszczące efekty działania efektu Forrestera podczas ostatniego kryzysu gospodarczego wskazał także Liu [2011, s. 20]. Podkreślił on, że w 2009 roku efekt Forrestera okazał się wyjątkowo silny, gdyż współczesne międzynarodowe łańcuchy (sieci) produkcyjne są o wiele dłuższe (bardziej rozbudowane) niż w przeszłości. O wpływie międzynarodowych czy nawet globalnych łańcuchów, których obecność prowadziła do wzmocnienia oddziaływania spadku popytu finalnego na międzynarodowy handel w czasie ostatniego kryzysu gospodarczego, również pisali: Eichengreen [2009], Yi [2011], Altomonte i inni [2012] oraz Zavacka [2012].

Przed ostatnim światowym kryzysem gospodarczym efekt Forrestera (nazywany także efektem wzmocnienia) był przede wszystkim tematem opracowań z zarządzania, ściślej zarządzania międzynarodowymi (globalnymi) łańcuchami dostaw [zob. np.: Mason-Jones, Towill, 2000; Disney, Towill, 2003; Tempelmeier, 2006]. Jednocześnie pojawiały się studia empiryczne dotyczące rosnącej roli dóbr pośrednich w handlu międzynarodowym [zob. np.: Kleinert, 2000; Peng, Ilinitch, 2001; Rauch, Watson, 2004].

Wspomniane dotychczas badania empiryczne opierały się na jednym sposobie mierzenia handlu międzynarodowego - za pomocą wybranej nomenklatury towarów ustalano podział na dobra finalne i pośrednie, a następnie szacowano wartości ich eksportu i/lub importu. Tymczasem badanie empiryczne zawarte w tym opracowaniu opiera się na dwóch sposobach mierzenia handlu - za pomoca międzynarodowej tablicy przepływów międzygałęziowych oraz nomenklatury BEC. To, że weryfikuje się występowanie efektu Forrestera na dwóch zbiorach danych statystycznych, autor tego artykułu uważa za wartość dodaną badania empirycznego.

Tablica przepływów międzygałęziowych (TPM) zawiera dane liczbowe charakteryzujące działalność gospodarcza w pewnym okresie (zwykle w ciagu roku), zestawione według określonego porządku. Koncepcja takiego zestawienia wiąże się z podziałem rozpatrywanego systemu gospodarczego (gospodarki narodowej - krajowa tablica przepływów międzygałęziowych lub gospodarki światowej - międzynarodowa tablica przepływów międzygałęziowych) na gałęzie (w przypadku międzynarodowej tablicy przepływów międzygałęziowych (MTPM) system gospodarczy jest dzielony na kraje i gałęzie) oraz z określeniem w przypadku każdej z nich wartości wytworzonej produkcji i sposobu jej wykorzystania. Dane te umieszcza się w tablicy, przeznaczając dla każdej gałęzi jeden wiersz, w którym występuje ona jako wytwórca (strona podażowa), jak również jedną kolumnę, gdzie funkcjonuje jako odbiorca produktów (strona popytowa) [Ekonometria, 1996, s. 370-371]. Wykorzystując TPM, można obliczyć wartość zużycia pośredniego (popytu na dobra pośrednie) i zużycia finalnego (popytu na dobra finalne) - w przypadku KTPM w skali kraju, zaś w przypadku MTPM w skali między- 
narodowej, czyli można wyznaczyć wartość eksportu (importu) dóbr pośrednich i finalnych. Drugim (choć mniej precyzyjnym) sposobem obliczenia wartości międzynarodowego handlu dobrami pośrednimi i finalnymi jest metoda posługująca się nomenklaturą BEC.

Nomenklatura BEC (Broad Economic Categories) została opracowana przez ONZ (United Nations Statistics Divisions) w drugiej połowie lat sześćdziesiątych XX wieku i umożliwia klasyfikację dóbr według ich wykorzystania gospodarczego (zgodnie z nomenklaturą BEC dobra dzieli się na 19 kategorii [zob. World Integrated Trade Solution]. Stosując ja do dóbr finalnych, zalicza się następujące dobra: nieprzetworzone żywność i napoje dla gospodarstw domowych (dział 112, według BEC), przetworzone żywność i napoje dla gospodarstw domowych (dział 122), samochody osobowe (dział 51), pozostałe dobra konsumpcyjne trwałego użytku (dział 61), pozostałe dobra konsumpcyjne półtrwałego użytku (dział 62) oraz pozostałe nietrwałe dobra konsumpcyjne (dział 63), zaś do dóbr pośrednich: nieprzetworzone żywność i napoje dla przemysłu (dział 111), nieprzetworzone towary wykorzystywane $\mathrm{w}$ przemyśle (dział 121), nieuwzględnione w innych działach (dział 21), nieprzetworzone towary wykorzystywane w przemyśle (dział 22), nieuwzględnione w innych działach, przetworzone paliwa i smary (działy: 321 i 322), dobra kapitałowe (z wyjątkiem środków transportu oraz ich części) i akcesoria do nich (działy: 41 i 42), a także części środków transportu i akcesoria do nich (dział 53). Dobra należące do działów: 31 (nieprzetworzone paliwa i smary), 521 i 522 (inne niż samochody osobowe środki transportu) i 7 (pozostałe towary nieuwzględnione w innych działach) nie dają się jednoznacznie zakwalifikować ani do dóbr pośrednich, ani do dóbr finalnych. Chociażby z tego powodu, wartości eksportu (importu) dóbr pośrednich i finalnych oszacowane na podstawie nomenklatury BEC sa mniej dokładne niż te obliczone z wykorzystaniem MTPM.

\section{Handel dobrami finalnymi i dobrami pośrednimi na podstawie MTPM}

Badanie empiryczne rozpoczęto od analizy wartości eksportu dóbr finalnych i pośrednich, obliczonych na podstawie MTPM. W 2009 roku nastapiły spadki wartości eksportu obu grup, przy czym bezwzględne spadki wartości eksportu dóbr pośrednich były większe (przeważnie kilkakrotnie większe) niż bezwzględne spadki wartości eksportu dóbr finalnych. Z kolei, względne spadki wartości eksportu dóbr pośrednich były silniejsze niż względne spadki wartości eksportu dóbr finalnych we wszystkich badanych gospodarkach, z wyjątkiem: Australii, Japonii, Szwajcarii i USA (tabela 2.). 
TABELA 1.

Wartości eksportu dóbr finalnych i pośrednich w latach 2008-2011 (MTPM, w mld USD)

\begin{tabular}{|l|r|r|r|r|r|r|r|r|}
\hline & \multicolumn{4}{|c|}{ Dobra finalne } & \multicolumn{4}{c|}{ Dobra pośrednie } \\
\cline { 2 - 8 } & \multicolumn{1}{|c|}{$\mathbf{2 0 0 8}$} & \multicolumn{1}{|c|}{$\mathbf{2 0 0 9}$} & \multicolumn{1}{|c|}{$\mathbf{2 0 1 0}$} & \multicolumn{2}{|c|}{$\mathbf{2 0 1 1}$} & \multicolumn{2}{c|}{$\mathbf{2 0 0 8}$} & \multicolumn{2}{c|}{$\mathbf{2 0 0 9}$} & \multicolumn{2}{c|}{$\mathbf{2 0 1 0}$} & \multicolumn{1}{c|}{$\mathbf{2 0 1 1}$} \\
\hline Australia & 32,8 & 25,8 & 31,5 & 37,2 & 131,4 & 106,2 & 159,2 & 194,0 \\
Islandia & 1,3 & 1,1 & 1,2 & 1,4 & 3,1 & 2,3 & 2,7 & 3,1 \\
Izrael & 20,5 & 17,8 & 20,1 & 22,7 & 27,5 & 22,2 & 26,7 & 30,7 \\
Japonia & 221,2 & 149,4 & 203,4 & 217,8 & 378,4 & 276,2 & 377,0 & 407,6 \\
Kanada & 99,9 & 83,9 & 97,3 & 108,4 & 272,7 & 187,1 & 235,2 & 284,2 \\
Korea Płd. & 130,7 & 112,1 & 143,3 & 169,0 & 246,1 & 209,9 & 274,2 & 327,7 \\
Norwegia & 24,0 & 17,2 & 16,9 & 20,0 & 119,4 & 83,3 & 93,6 & 118,2 \\
Nowa Zelandia & 11,1 & 9,0 & 11,3 & 13,5 & 13,1 & 10,4 & 14,4 & 16,4 \\
Szwajcaria & 65,9 & 57,6 & 61,8 & 73,4 & 101,1 & 89,2 & 101,0 & 120,4 \\
UE-28 & 1648,8 & 1283,4 & 1388,8 & 1597,0 & 2428,3 & 1801,3 & 2045,5 & 2433,6 \\
USA & 427,8 & 345,1 & 400,7 & 462,5 & 607,2 & 493,6 & 595,5 & 686,6 \\
\hline
\end{tabular}

Źródło: opracowanie własne na podstawie: [Measuring Trade in V alue Added...].

W 2010 roku wartości eksportu dóbr finalnych i pośrednich wzrosły (z wyjątkiem Norwegii), ale były niższe (z wyjątkiem Korei Południowej i Nowej Zelandii) od wartości eksportu z 2008 roku (tabela 1.). W wartościach bezwzględnych wzrosty wartości eksportu dóbr pośrednich przewyższyły wzrosty wartości dóbr finalnych. Podobnie było w przypadku wzrostów w wartościach względnych (tabela 2.).

TABELA 2.

Zmiany wartości eksportu dóbr finalnych i pośrednich w latach 2008-2011 (MTPM, w mld USD i zmiany względne)

\begin{tabular}{|l|c|c|c|c|c|c|c|c|}
\hline & \multicolumn{5}{|c|}{ Dobra finalne } & \multicolumn{3}{c|}{ Dobra pośrednie } \\
\cline { 2 - 8 } & $\mathbf{2 0 0 9 /}$ & $\mathbf{2 0 1 0 /}$ & $\mathbf{2 0 1 1 /}$ & $\mathbf{2 0 1 1 /}$ & $\mathbf{2 0 0 9 /}$ & $\mathbf{2 0 1 0 /}$ & $\mathbf{2 0 1 1 /}$ & $\mathbf{2 0 1 1 /}$ \\
& $\mathbf{2 0 0 8}$ & $\mathbf{2 0 0 9}$ & $\mathbf{2 0 1 0}$ & $\mathbf{2 0 0 8}$ & $\mathbf{2 0 0 8}$ & $\mathbf{2 0 0 9}$ & $\mathbf{2 0 1 0}$ & $\mathbf{2 0 0 8}$ \\
\hline Australia & $-7,0(-21 \%)$ & $5,7(22 \%)$ & $5,7(18 \%)$ & $4,4(13 \%)$ & $-25,2(-19 \%)$ & $53,0(50 \%)$ & $34,8(22 \%)$ & $62,6(48 \%)$ \\
Islandia & $-0,2(-15 \%)$ & $0,1(9 \%)$ & $0,2(17 \%)$ & $0,1(8 \%)$ & $-0,8(-26 \%)$ & $0,4(70 \%)$ & $0,4(15 \%)$ & $0,0(0 \%)$ \\
Izrael & $-2,7(-13 \%)$ & $2,3(13 \%)$ & $2,6(13 \%)$ & $2,2(11 \%)$ & $-5,3(-19 \%)$ & $4,5(20 \%)$ & $4,0(15 \%)$ & $3,2(12 \%)$ \\
Japonia & $-71,8(-32 \%)$ & $54,0(36 \%)$ & $14,4(7 \%)$ & $-3,4(-2 \%)$ & $-102,2(-27 \%)$ & $100,8(36 \%)$ & $30,6(8 \%)$ & $29,2(8 \%)$ \\
Kanada & $-16,0(-16 \%)$ & $13,4(16 \%)$ & $11,1(11 \%)$ & $8,5(9 \%)$ & $-85,6(-31 \%)$ & $48,1(26 \%)$ & $49,0(21 \%)$ & $11,5(4 \%)$ \\
Korea Płd. & $-18,6(-14 \%)$ & $31,2(28 \%)$ & $25,7(18 \%)$ & $38,3(29 \%)$ & $-36,2(-15 \%)$ & $64,3(31 \%)$ & $53,5(20 \%)$ & $81,6(33 \%)$ \\
Norwegia & $-6,8(-28 \%)$ & $-0,3(-2 \%)$ & $3,1(18 \%)$ & $-4,0(-17 \%)$ & $-36,1(-30 \%)$ & $10,3(12 \%)$ & $24,6(26 \%)$ & $-1,2(-1 \%)$ \\
Nowa Zelandia & $-2,1(-19 \%)$ & $2,3(26 \%)$ & $2,2(19 \%)$ & $2,4(22 \%)$ & $-2,7(-21 \%)$ & $4,0(38 \%)$ & $2,0(14 \%)$ & $3,3(25 \%)$ \\
Szwajcaria & $-8,3(-13 \%)$ & $4,2(7 \%)$ & $11,6(19 \%)$ & $7,5(11 \%)$ & $-11,9(-12 \%)$ & $11,8(13 \%)$ & $19,4(19 \%)$ & $19,3(19 \%)$ \\
UE-28 & $-365,4(-22 \%)$ & $105,4(8 \%)$ & $208,2(15 \%)$ & $-51,8(-3 \%)$ & $-627,0(-26 \%)$ & $244,2(14 \%)$ & $388,1(19 \%)$ & $5,3(0 \%)$ \\
USA & $-82,7(-19 \%)$ & $55,6(16 \%)$ & $61,8(15 \%)$ & $34,7(8 \%)$ & $-113,6(-19 \%)$ & $101,9(21 \%)$ & $91,1(15 \%)$ & $79,4(13 \%)$ \\
\hline
\end{tabular}

Źródło: opracowanie własne na podstawie: [Measuring Trade in V alue Added...]. 
W 2011 roku miały miejsce kolejne wzrosty wartości eksportu obu grup dóbr. Poza: Islandia, Nową Zelandią oraz USA, względne wzrosty wartości eksportu dóbr pośrednich były większe niż względne wzrosty wartości eksportu dóbr finalnych (bezwzględne wzrosty wartości eksportu dóbr pośrednich przewyższyły bezwzględne wzrosty wartości eksportu dóbr finalnych we wszystkich badanych gospodarkach) (tabela 2.). W 2011 roku wartości eksportu dóbr finalnych wciąż pozostawały niższe od wartości osiagniętych w 2008 roku, w przypadku: Japonii, Norwegii oraz UE-28. Z kolei, w odniesieniu do eksportu dóbr pośrednich taki stan rzeczy charakteryzował tylko Norwegię (tabela 1.).

TABELA 3.

Wartości importu dóbr finalnych i pośrednich w latach 2008-2011 (MTPM, w mld USD)

\begin{tabular}{|c|c|c|c|c|c|c|c|c|}
\hline & \multicolumn{4}{|c|}{ Dobra finalne } & \multicolumn{4}{|c|}{ Dobra pośrednie } \\
\hline & 2008 & 2009 & 2010 & 2011 & 2008 & 2009 & 2010 & 2011 \\
\hline Australia & 79,7 & 69,6 & 86,4 & 109,6 & 80,1 & 68,7 & 88,2 & 115,2 \\
\hline Islandia & 1,6 & 0,8 & 0,9 & 1,1 & 2,6 & 1,8 & 2,0 & 2,4 \\
\hline Izrael & 21,6 & 16,4 & 18,8 & 24,8 & 32,0 & 22,4 & 29,3 & 34,7 \\
\hline Japonia & 176,9 & 130,9 & 156,4 & 186,7 & 441,3 & 302,0 & 395,2 & 508,8 \\
\hline Kanada & 129,7 & 110,3 & 129,4 & 150,9 & 201,8 & 160,1 & 206,8 & 234,0 \\
\hline Korea Płd. & 58,9 & 45,1 & 59,4 & 69,0 & 306,5 & 228,2 & 305,1 & 382,8 \\
\hline Norwegia & 29,2 & 21,9 & 27,1 & 30,7 & 43,3 & 36,6 & 39,4 & 45,8 \\
\hline Nowa Zelandia & 11,8 & 9,0 & 11,8 & 14,0 & 14,5 & 10,0 & 12,8 & 14,9 \\
\hline Szwajcaria & 70,5 & 60,4 & 68,0 & 82,1 & 85,8 & 72,9 & 82,3 & 95,2 \\
\hline UE-28 & 1562,2 & 1218,7 & 1299,9 & 1461,2 & 2602,8 & 1835,5 & 2111,5 & 2550,6 \\
\hline USA & 613,8 & 507,0 & 588,0 & 652,7 & 1111,6 & 738,0 & 941,4 & 1103,0 \\
\hline
\end{tabular}

Źródło: opracowanie własne na podstawie: [Measuring Trade in V alue Added...].

Tendencje zmian wartości importu dóbr finalnych i pośrednich w latach 2008-2011 były zbliżone do opisanych właśnie trendów w eksporcie obu grup dóbr. Oznacza to, że poza kilkoma wyjątkami, zmiany wartości importu obu grup dóbr potwierdziły występowanie efektu Forrestera. Przykładowe wyjątki stanowiły względne spadki wartości importu dóbr finalnych Islandii i Norwegii w 2009 roku, które były większe niż względne spadki wartości importu dóbr pośrednich. Ponadto, w tych dwóch państwach i Nowej Zelandii również względne wzrosty wartości importu dóbr finalnych w 2010 roku przewyższyły względne wzrosty wartości importu dóbr pośrednich (w Norwegii także bezwzględne wzrosty). Co więcej, efektu Forrestera nie potwierdziły w 2011 roku bezwzględne wzrosty wartości importu Izraela, Nowej Zelandii i Szwajcarii, względne wzrosty wartości importu w 2011 roku, w: Islandii, Izraelu, Kanadzie, Nowej Zelandii i Szwajcarii (tabela 4.). 
TABELA 4.

Zmiany wartości importu dóbr finalnych i pośrednich w latach 2008-2011 (MTPM, w mld USD i zmiany względne)

\begin{tabular}{|l|c|c|c|c|c|c|c|c|}
\hline & \multicolumn{6}{|c|}{ Dobra finalne } & \multicolumn{4}{c|}{ Dobra pośrednie } \\
\cline { 2 - 8 } & $\mathbf{2 0 0 9 /}$ & $\mathbf{2 0 1 0 /}$ & $\mathbf{2 0 1 1 /}$ & $\mathbf{2 0 1 1 /}$ & $\mathbf{2 0 0 9 /}$ & $\mathbf{2 0 1 0 /}$ & $\mathbf{2 0 1 1 /}$ & $\mathbf{2 0 1 1 /}$ \\
& $\mathbf{2 0 0 8}$ & $\mathbf{2 0 0 9}$ & $\mathbf{2 0 1 0}$ & $\mathbf{2 0 0 8}$ & $\mathbf{2 0 0 8}$ & $\mathbf{2 0 0 9}$ & $\mathbf{2 0 1 0}$ & $\mathbf{2 0 0 8}$ \\
\hline Australia & $-10,1(-13 \%)$ & $16,8(24 \%)$ & $23,2(27 \%)$ & $29,9(38 \%)$ & $-11,4(-14 \%)$ & $19,5(28 \%)$ & $27,0(31 \%)$ & $35,1(44 \%)$ \\
Islandia & $-0,8(-50 \%)$ & $0,1(13 \%)$ & $0,2(22 \%)$ & $-0,5(-31 \%)$ & $-0,8(-31 \%)$ & $0,2(11 \%)$ & $0,4(20 \%)$ & $-0,2(-8 \%)$ \\
Izrael & $-5,2(-24 \%)$ & $2,4(15 \%)$ & $6,0(32 \%)$ & $3,2(15 \%)$ & $-9,6(-30 \%)$ & $6,9(31 \%)$ & $5,4(18 \%)$ & $2,7(8 \%)$ \\
Japonia & $-46,0(-26 \%)$ & $25,5(19 \%)$ & $30,3(19 \%)$ & $9,8(6 \%)$ & $-139,3(-32 \%)$ & $93,2(31 \%)$ & $113,6(29 \%)$ & $67,5(15 \%)$ \\
Kanada & $-19,4(-15 \%)$ & $19,1(17 \%)$ & $21,5(17 \%)$ & $21,2(16 \%)$ & $-41,7(-21 \%)$ & $46,7(29 \%)$ & $27,2(13 \%)$ & $32,2(16 \%)$ \\
Korea Płd. & $-13,8(-23 \%)$ & $14,3(32 \%)$ & $9,6(16 \%)$ & $10,1(17 \%)$ & $-78,3(-26 \%)$ & $76,9(34 \%)$ & $77,7(25 \%)$ & $76,3(25 \%)$ \\
Norwegia & $-7,3(-25 \%)$ & $5,2(24 \%)$ & $3,6(13 \%)$ & $1,5(5 \%)$ & $-6,7(-15 \%)$ & $2,8(8 \%)$ & $6,4(16 \%)$ & $2,5(6 \%)$ \\
Nowa Zelandia & $-2,8(-24 \%)$ & $2,8(31 \%)$ & $2,2(19 \%)$ & $2,2(19 \%)$ & $-4,5(-31 \%)$ & $2,8(28 \%)$ & $2,1(16 \%)$ & $0,4(3 \%)$ \\
Szzajcaria & $-10,1(-14 \%)$ & $7,6(13 \%)$ & $14,1(21 \%)$ & $11,6(16 \%)$ & $-12,9(-15 \%)$ & $9,4(13 \%)$ & $12,9(16 \%)$ & $9,4(11 \%)$ \\
UE-28 & $-343,5(-22 \%)$ & $81,2(7 \%)$ & $161,3(12 \%)$ & $-101,0(-6 \%)$ & $-767,3(-29 \%)$ & $276,0(15 \%)$ & $439,1(21 \%)$ & $-52,2(-2 \%)$ \\
USA & $-106,8(-17 \%)$ & $81,0(6 \%)$ & $64,7(11 \%)$ & $38,9(6 \%)$ & $-373,6(-34 \%)$ & $203,4(28 \%)$ & $161,6(17 \%)$ & $-8,6(-1 \%)$ \\
\hline
\end{tabular}

Źródło: opracowanie własne na podstawie: [Measuring Trade in V alue Added...].

W 2011 roku wartości eksportu dóbr finalnych wciąż pozostawały niższe od wartości osiagniętych w 2008 roku w Islandii oraz UE-28. Z kolei, w przypadku eksportu dóbr pośrednich taki stan rzeczy charakteryzował również USA (tabela 3.). Zatem w stosunku do importu skutki załamania handlu międzynarodowego w 2009 roku okazały się poważniejsze niż w przypadku eksportu. Może to być konsekwencją częstszego stosowania instrumentów protekcji przez państwa wysoko rozwinięte po 2008 roku niż przed wybuchem światowego kryzysu gospodarczego.

\section{Handel dobrami finalnymi i dobrami pośrednimi według nomenklatury BEC}

Wartości eksportu dóbr finalnych mierzone dzięki wykorzystaniu nomenklatury BEC były przeważnie niższe (wyjątkiem były dane dotyczące: Islandii, UE-28 i Szwajcarii) niż wartości eksportu obliczone na podstawie MTPM (tabele: 5. i 1.). Prawdopodobnie jest to następstwem tego, że dobra należące do działów: 31 (nieprzetworzone paliwa i smary), 521 i 522 (inne niż samochody osobowe środki transportu) oraz 7 (pozostałe towary nieuwzględnione w innych działach) nie dają się jednoznacznie zakwalifikować ani do dóbr pośrednich, ani do dóbr finalnych. Jednak generalnie rząd wielkości jest podobny - tzn. jeżeli według MPTM wartości eksportu jakiegoś kraju wynoszą np. kilka mld USD, to również dzięki wykorzystaniu nomenklatury BEC wartości te są równe kilku mld USD. Największe rozbieżności między wartościami eksportu mierzonego na dwa sposoby wystapiły w Korei Południowej i USA. Należy przypuszczać, że w eksporcie tych państw dużą rolę odgrywają dobra ze wspomnianych działów: 31, 521, 522 i 7 (zapewne chodzi przede wszystkim o eksport środków transportu o względnie wysokich cenach).

Z kolei, w przypadku eksportu dóbr pośrednich sytuacja była odwrotna - tzn. wartości obliczone na podstawie nomenklatury BEC były przeważnie wyższe (z wyjątkiem: Australii, Islandii i Norwegii) od tych oszacowanych na podstawie MTPM. Największe roz- 
bieżności dotyczyły UE-28 i USA (tabele: 5. i 1.). Taki stan rzeczy sugeruje, że niektóre dobra, zakwalifikowane według nomenklatury BEC do dóbr pośrednich, być może to powinny być uznane za dobra finalne. Może to dotyczyć dóbr kapitałowych z działów: 41 i 42.

TABELA 5.

\section{Wartości eksportu dóbr finalnych i pośrednich w latach 2008-2011} (nomenklatura BEC, w mld USD)

\begin{tabular}{|c|c|c|c|c|c|c|c|c|}
\hline & \multicolumn{4}{|c|}{ Dobra finalne } & \multicolumn{4}{|c|}{ Dobra pośrednie } \\
\hline & 2008 & 2009 & 2010 & 2011 & 2008 & 2009 & 2010 & 2011 \\
\hline Australia & 22,6 & 18,6 & 22,0 & 24,8 & 107,6 & 90,4 & 130,0 & 172,9 \\
\hline Islandia & 2,0 & 1,7 & 1,9 & 2,2 & 2,9 & 2,1 & 2,6 & 3,0 \\
\hline Izrael & 9,6 & 8,8 & 11,0 & 11,7 & 50,3 & 38,3 & 46,9 & 55,4 \\
\hline Japonia & 145,2 & 86,9 & 118,8 & 117,6 & 555,0 & 423,7 & 566,4 & 620,1 \\
\hline Kanada & 69,0 & 55,4 & 71,3 & 76,5 & 236,5 & 164,1 & 204,5 & 238,2 \\
\hline Korea Płd. & 49,3 & 39,5 & 52,0 & 63,6 & 333,8 & 283,4 & 372,7 & 448,7 \\
\hline Norwegia & 14,8 & 12,5 & 15,6 & 19,1 & 11,5 & 9,2 & 11,4 & 13,8 \\
\hline Nowa Zelandia & 9,4 & 9,1 & 11,1 & 11,8 & 48,3 & 36,0 & 39,5 & 47,0 \\
\hline Szwajcaria & 69,6 & 64,0 & 71,2 & 86,7 & 123,3 & 102,0 & 118,5 & 140,9 \\
\hline UE-28 & 1530,9 & 1313,0 & 1407,8 & 1604,8 & 3699,1 & 2727,4 & 3164,0 & 3839,0 \\
\hline USA & 183,2 & 157,2 & 176,9 & 198,2 & 857,5 & 642,4 & 791,6 & 927,9 \\
\hline
\end{tabular}

Źródło: opracowanie własne na podstawie: [World Integrated Trade Solution].

Natomiast, jeżeli chodzi o weryfikację występowania efektu Forrestera na podstawie wartości eksportu obliczonych z wykorzystaniem nomenklatury BEC, to sytuacja była bardzo podobna jak w przypadku wartości eksportu oszacowanych na podstawie MTPM. W 2009 roku, z wyjątkiem: Australii, Japonii i Korei Południowej, względne spadki wartości eksportu dóbr finalnych były mniejsze niż względne spadki wartości eksportu dóbr pośrednich (w przypadku wartości bezwzględnych nie wystąpiły żadne odstępstwa od efektu Forrestera) (tabela 6.). Więcej wyjątków objęło lata 2010 i 2011, w których w kilku państwach wartości eksportu dóbr finalnych rosły szybciej niż wartości eksportu dóbr pośrednich (chodzi o zmiany względne).

Wartości importu obu rodzajów grup dóbr, wyznaczone dzięki wykorzystaniu nomenklatury BEC, również różniły się od wartości importu dóbr finalnych i pośrednich obliczonych na podstawie MTPM (tabele: 7. i 3.). Jednak wydaje się, że rozbieżności były mniejsze niż w przypadku wartości eksportu (zwłaszcza dla USA), co może wynikać z różnego sposobu gromadzenia danych dotyczacych eksportu i importu. Otóż te pierwsze pochodziły najczęściej z deklaracji podatkowych przedsiębiorstw, zaś te drugie ze sprawozdań (deklaracji) celnych. W rezultacie, dane dotyczące importu przeważnie były bardziej dokładne, jeżeli chodzi o cechy danego dobra, stąd przyporządkowanie do jednego z działów nomenklatury BEC prawdopodobnie jest bardziej poprawne niż to na podstawie informacji dostarczanych przez przedsiębiorstwa. Warto wspomnieć w tym miejscu, że stosowanie przez wiele państw instrumentów protekcji, powodujących wzrost cen dóbr importowanych, mogło wywoływać wzrost wartości importu. Z kolei, w celu minimalizacji obciążeń podatkowych, przedsiębiorstwa mogły zaniżać wartości eksportu w deklaracjach podatkowych. Wszystko to dodatko- 
wo komplikuje analizę przyczyn rozbieżności między wartościami handlu mierzonego za pomoca MTPM oraz nomenklatury BEC.

TABELA 6.

Zmiany wartości eksportu dóbr finalnych i pośrednich w latach 2008-2011 (nomenklatura BEC, w mld USD i zmiany względne)

\begin{tabular}{|c|c|c|c|c|c|c|c|c|}
\hline & \multicolumn{4}{|c|}{ Dobra finalne } & \multicolumn{4}{|c|}{ Dobra pośrednie } \\
\hline & $\begin{array}{c}2009 / \\
2008\end{array}$ & \begin{tabular}{c|}
$2010 /$ \\
2009
\end{tabular} & $\begin{array}{r}2011 / \\
2010\end{array}$ & $\begin{array}{c}2011 / \\
2008\end{array}$ & $\begin{array}{c}2009 / \\
2008\end{array}$ & $\begin{array}{c}2010 / \\
2009\end{array}$ & $\begin{array}{r}2011 / \\
2010\end{array}$ & $\begin{array}{l}2011 / \\
2008\end{array}$ \\
\hline & $-4,0(-18 \%)$ & $3,4(18 \%)$ & $2,8(13 \%)$ & $2,2(10 \%)$ & $-17,2(-16 \%)$ & $39,6(44 \%)$ & $42,9(33 \%)$ & $65,3(61 \%)$ \\
\hline Islandia & $-0,3(-15 \%)$ & $0,2(12 \%)$ & $0,3(16 \%)$ & $0,2(10 \%)$ & $-0,8(-28 \%)$ & $0,5(24 \%)$ & $0,4(15 \%)$ & $0,1(3 \%)$ \\
\hline Izrael & $-0,8(-8 \%)$ & $2,2(25 \%)$ & $0,7(6 \%)$ & $2,1(22 \%)$ & $-12,0(-24 \%)$ & $8,6(22 \%)$ & $8,5(18 \%)$ & $5,1(10 \%)$ \\
\hline Japonia & $-58,3(-40 \%)$ & $31,9(37 \%)$ & $-1,2(-1 \%)$ & $-27,6(-19 \%)$ & $-131,3(-24 \%)$ & $142,7(34 \%)$ & $53,7(9 \%)$ & $65,1(12 \%)$ \\
\hline Kanada & $-13,6(-20 \%)$ & $15,9(29 \%)$ & $5,2(7 \%)$ & $7,5(11 \%)$ & $-72,4(-31 \%)$ & $40,4(25 \%)$ & $33,7(16 \%)$ & $1,7(1 \%)$ \\
\hline Korea Płd. & $-9,8(-20 \%)$ & $12,5(32 \%)$ & $11,6(22 \%)$ & $14,3(29 \%)$ & $-50,4(-15 \%)$ & $89,3(32 \%)$ & $76,0(20 \%)$ & $114,9(34 \%)$ \\
\hline Norwegia & $-2,3(-16 \%)$ & $3,1(25 \%)$ & $3,5(22 \%)$ & $4,3(29 \%)$ & $-2,3(-20 \%)$ & $2,2(24 \%)$ & $2,4(21 \%)$ & $2,3(20 \%)$ \\
\hline Nowa Zelandia & $-0,3(-3 \%)$ & $2,0(22 \%)$ & $0,7(6 \%)$ & $2,4(26 \%)$ & $-12,3(-25 \%)$ & $3,5(10 \%)$ & $7,5(19 \%)$ & $-1,3(-3 \%)$ \\
\hline Szzwajcaria & $-5,6(-8 \%)$ & $7,2(11 \%)$ & $15,5(22 \%)$ & $17,1(25 \%)$ & $-21,3(-17 \%)$ & $16,5(16 \%)$ & $22,4(19 \%)$ & $17,6(14 \%)$ \\
\hline UE-28 & $-217,9(-14 \%)$ & $94,8(7 \%)$ & $197,0(14 \%)$ & $73,9(5 \%)$ & $-971,7(-26 \%)$ & $436,6(16 \%)$ & $675,0(21 \%)$ & $139,9(4 \%)$ \\
\hline USA & $-26,0(-14 \%)$ & $19,7(13 \%)$ & $21,3(12 \%)$ & $15,0(8 \%)$ & $-215,1(-25 \%)$ & $149,2(23 \%)$ & $136,3(17 \%)$ & $70,4(8 \%)$ \\
\hline
\end{tabular}

Źródło: opracowanie własne na podstawie: [World Integrated Trade Solution].

TABELA 7.

Wartości importu dóbr finalnych i pośrednich w latach 2008-2011 (nomenklatura BEC, w mld USD)

\begin{tabular}{|c|c|c|c|c|c|c|c|c|}
\hline & \multicolumn{4}{|c|}{ Dobra finalne } & \multicolumn{4}{|c|}{ Dobra pośrednie } \\
\hline & 2008 & 2009 & 2010 & 2011 & 2008 & 2009 & 2010 & 2011 \\
\hline Australia & 53,1 & 48,0 & 59,8 & 63,4 & 115,3 & 94,2 & 109,3 & 129,1 \\
\hline Islandia & 1,6 & 1,0 & 1,0 & 1,2 & 4,2 & 2,5 & 2,8 & 3,5 \\
\hline Izrael & 11,4 & 10,5 & 12,1 & 13,7 & 42,0 & 29,0 & 37,3 & 47,9 \\
\hline Japonia & 133,1 & 129,6 & 146,7 & 174,9 & 425,1 & 304,2 & 399,7 & 489,6 \\
\hline Kanada & 103,8 & 89,9 & 102,6 & 109,6 & 237,6 & 185,9 & 231,7 & 273,0 \\
\hline Korea Płd. & 32,2 & 26,8 & 34,4 & 42,7 & 298,8 & 231,1 & 303,4 & 355,9 \\
\hline Norwegia & 9,5 & 8,0 & 9,6 & 10,6 & 19,7 & 14,3 & 16,0 & 19,4 \\
\hline Nowa Zelandia & 22,7 & 19,5 & 22,1 & 25,1 & 57,0 & 42,4 & 46,2 & 56,6 \\
\hline Szwajcaria & 60,2 & 57,8 & 64,3 & 74,5 & 111,5 & 89,4 & 101,8 & 122,1 \\
\hline UE-28 & 1514,5 & 1292,1 & 1353,4 & 1509,5 & 3574,8 & 2559,8 & 3042,1 & 3676,3 \\
\hline USA & 570,2 & 472,9 & 562,1 & 591,9 & 1097,9 & 828,8 & 1032,3 & 1215,1 \\
\hline
\end{tabular}

Źródło: opracowanie własne na podstawie: [World Integrated Trade Solution].

Zdecydowanie łatwiej jest dokonać weryfikacji występowania efektu Forrestera na podstawie wartości importu dóbr finalnych i pośrednich, oszacowanych dzięki wykorzystaniu nomenklatury BEC. Otóż, poza czterema wyjątkami (Australia, Norwegia i Nowa Zelandia w 2010 roku oraz Korea Południowa w 2011 roku), bezwzględne i względne zmiany wartości importu dóbr pośrednich były silniejsze niż zmiany wartości importu dóbr finalnych, co potwierdza występowanie efektu Forrestera (tabela 8.). 
TABELA 8.

Zmiany wartości importu dóbr finalnych i pośrednich w latach 2008-2011 (nomenklatura BEC, w mld USD i zmiany względne)

\begin{tabular}{|l|r|r|r|r|r|r|r|r|}
\hline & \multicolumn{7}{|c|}{ Dobra finalne } & \multicolumn{3}{|c|}{ Dobra pośrednie } \\
\cline { 2 - 8 } & \multicolumn{1}{|c|}{$\mathbf{2 0 0 9 /}$} & $\mathbf{2 0 1 0 /}$ & \multicolumn{1}{c|}{$\mathbf{2 0 1 1 /}$} & \multicolumn{1}{c|}{$\mathbf{2 0 1 1 /}$} & \multicolumn{1}{c|}{$\mathbf{2 0 0 9 /}$} & $\mathbf{2 0 1 0 /}$ & \multicolumn{1}{c|}{$\mathbf{2 0 1 1 /}$} & $\mathbf{2 0 1 1 /}$ \\
& $\mathbf{2 0 0 8}$ & $\mathbf{2 0 0 9}$ & $\mathbf{2 0 1 0}$ & $\mathbf{2 0 0 8}$ & $\mathbf{2 0 0 8}$ & $\mathbf{2 0 0 9}$ & $\mathbf{2 0 1 0}$ & $\mathbf{2 0 0 8}$ \\
\hline Australia & $-5,1(-10 \%)$ & $11,8(25 \%)$ & $3,6(6 \%)$ & $10,3(19 \%)$ & $-21,1(-18 \%)$ & $15,1(16 \%)$ & $19,8(18 \%)$ & $13,8(12 \%)$ \\
Islandia & $-0,6(-38 \%)$ & $0,0(0 \%)$ & $0,2(20 \%)$ & $-0,4(-25 \%)$ & $-1,7(-40 \%)$ & $0,3(12 \%)$ & $0,7(25 \%)$ & $-0,7(-17 \%)$ \\
Izrael & $-0,9(-8 \%)$ & $1,6(15 \%)$ & $1,6(13 \%)$ & $2,3(20 \%)$ & $-13,0(-31 \%)$ & $8,3(29 \%)$ & $10,6(28 \%)$ & $5,9(14 \%)$ \\
Japonia & $-3,5(-3 \%)$ & $17,1(13 \%)$ & $28,2(19 \%)$ & $41,8(31 \%)$ & $-120,9(-28 \%)$ & $95,5(31 \%)$ & $89,9(22 \%)$ & $64,5(15 \%)$ \\
Kanada & $-13,9(-13 \%)$ & $12,7(14 \%)$ & $7,0(7 \%)$ & $5,8(6 \%)$ & $-51,7(-22 \%)$ & $45,8(25 \%)$ & $41,3(18 \%)$ & $35,4(15 \%)$ \\
Korea Płd. & $-5,4(-17 \%)$ & $7,6(28 \%)$ & $8,3(24 \%)$ & $10,5(33 \%)$ & $-67,7(-23 \%)$ & $72,3(31 \%)$ & $52,5(17 \%)$ & $57,1(19 \%)$ \\
Norwegia & $-1,5(-16 \%)$ & $1,6(20 \%)$ & $1,0(10 \%)$ & $1,1(12 \%)$ & $-5,4(-27 \%)$ & $1,7(12 \%)$ & $3,4(21 \%)$ & $-0,3(-2 \%)$ \\
Nowa Zelandia & $-3,2(-14 \%)$ & $2,6(13 \%)$ & $3,0(14 \%)$ & $2,4(11 \%)$ & $-14,6(-26 \%)$ & $3,8(9 \%)$ & $10,4(23 \%)$ & $-0,4(-1 \%)$ \\
Szwajcaria & $-2,4(-4 \%)$ & $6,5(11 \%)$ & $10,2(16 \%)$ & $14,3(24 \%)$ & $-22,1(-20 \%)$ & $12,4(14 \%)$ & $20,3(20 \%)$ & $10,6(10 \%)$ \\
UE-28 & $-222,4(-15 \%)$ & $61,3(5 \%)$ & $156,1(12 \%)$ & $-5,0(0 \%)$ & $-1015,0(-28 \%)$ & $482,3(19 \%)$ & $634,2(21 \%)$ & $101,5(3 \%)$ \\
USA & $-97,3(-17 \%)$ & $89,2(19 \%)$ & $29,8(5 \%)$ & $21,7(4 \%)$ & $-269,1(-25 \%)$ & $203,5(25 \%)$ & $182,8(18 \%)$ & $117,2(11 \%)$ \\
\hline
\end{tabular}

Źródło: opracowanie własne na podstawie: [World Integrated Trade Solution].

Na koniec rozważań, dotyczących handlu dobrami finalnymi i dobrami pośrednimi, analizie poddano wartości handlu dóbr pośrednich przypadające na jednostkę wartości handlu dobrami finalnymi (tabele: 9. i 10.). Okazuje się, że wartość eksportu i importu dóbr pośrednich, przypadająca na 1 USD eksportu i importu dóbr finalnych, była przeważnie większa od jedności, bez względu na sposób pomiaru handlu. Świadczy to o tym, że dobra pośrednie są coraz ważniejszym przedmiotem handlu międzynarodowego. Trudno temu dziwić się w obliczu postępującego umiędzynarodowienia produkcji. Jednak rosnący handel dobrami pośrednimi o różnym stopniu przetworzenia powoduje również wielokrotne przekraczanie granic przez dobra pośrednie, a w konsekwencji zawyżanie wartości handlu.

TABELA 9.

Wartości eksportu dóbr pośrednich na jednostkę wartości eksportu dóbr finalnych w latach 2008-2011

\begin{tabular}{|l|c|c|c|c|c|c|c|c|}
\hline \multirow{2}{*}{} & \multicolumn{4}{|c|}{ MTPM } & \multicolumn{4}{c|}{ Nomenklatura BEC } \\
\cline { 2 - 9 } & $\mathbf{2 0 0 8}$ & $\mathbf{2 0 0 9}$ & $\mathbf{2 0 1 0}$ & $\mathbf{2 0 1 1}$ & $\mathbf{2 0 0 8}$ & $\mathbf{2 0 0 9}$ & $\mathbf{2 0 1 0}$ & $\mathbf{2 0 1 1}$ \\
\hline Australia & 4,0 & 4,1 & 5,1 & 5,2 & 4,8 & 4,9 & 5,9 & 7,0 \\
Islandia & 2,4 & 2,1 & 2,3 & 2,2 & 1,5 & 1,2 & 1,4 & 1,4 \\
Izrael & 1,3 & 1,2 & 1,3 & 1,4 & 5,2 & 4,4 & 4,3 & 4,7 \\
Japonia & 1,7 & 1,8 & 1,9 & 1,9 & 3,8 & 4,9 & 4,8 & 5,3 \\
Kanada & 2,7 & 2,2 & 2,4 & 2,6 & 3,4 & 3,0 & 2,9 & 3,1 \\
Korea Płd. & 1,9 & 1,9 & 1,9 & 1,9 & 6,8 & 7,2 & 7,2 & 7,1 \\
Norwegia & 5,0 & 4,8 & 5,5 & 5,9 & 0,8 & 0,7 & 0,7 & 0,7 \\
Nowa Zelandia & 1,2 & 1,2 & 1,3 & 1,2 & 5,1 & 4,0 & 3,6 & 4,0 \\
Szwajcaria & 1,5 & 1,5 & 1,6 & 1,6 & 1,8 & 1,6 & 1,7 & 1,6 \\
UE-28 & 1,5 & 1,4 & 1,5 & 1,5 & 2,4 & 2,1 & 2,2 & 2,4 \\
USA & 1,4 & 1,4 & 1,5 & 1,5 & 4,7 & 4,1 & 4,5 & 4,7 \\
\hline
\end{tabular}

Źródło: opracowanie własne. 
Problem zawyżonych wartości handlu, czyli wielokrotnego liczenia handlu tymi samymi dobrami, był bardziej widoczny w przypadku danych opartych na nomenklaturze BEC. Po raz kolejny potwierdza to, że dane obliczone na jej podstawie są mniej dokładne niż dane oszacowane na podstawie MTPM. Aczkolwiek całkowite wyeliminowanie problemu wielokrotnego naliczenia handlu tymi samymi dobrami jest możliwe tylko dzięki obliczeniu handlu wartością dodaną, zamiast handlu mierzonego wartością brutto dóbr [szerzej zob.: Folfas, 2016].

TABELA 10.

Wartości importu dóbr pośrednich na jednostkę wartości eksportu dóbr finalnych w latach 2008-2011

\begin{tabular}{|l|c|c|c|c|c|c|c|c|}
\hline \multirow{2}{*}{} & \multicolumn{4}{|c|}{ MTPM } & \multicolumn{4}{c|}{ Nomenklatura BEC } \\
\cline { 2 - 8 } & $\mathbf{2 0 0 8}$ & $\mathbf{2 0 0 9}$ & $\mathbf{2 0 1 0}$ & $\mathbf{2 0 1 1}$ & $\mathbf{2 0 0 8}$ & $\mathbf{2 0 0 9}$ & $\mathbf{2 0 1 0}$ & $\mathbf{2 0 1 1}$ \\
\hline Australia & 1,0 & 1,0 & 1,0 & 1,1 & 2,2 & 2,0 & 1,8 & 2,0 \\
Islandia & 1,6 & 2,3 & 2,2 & 2,2 & 2,6 & 2,5 & 2,8 & 2,9 \\
Izrael & 1,5 & 1,4 & 1,6 & 1,4 & 3,7 & 2,8 & 3,1 & 3,5 \\
Japonia & 2,5 & 2,3 & 2,5 & 2,7 & 3,2 & 2,3 & 2,7 & 2,8 \\
Kanada & 1,6 & 1,5 & 1,6 & 1,6 & 2,3 & 2,1 & 2,3 & 2,5 \\
Korea Płd. & 5,2 & 5,1 & 5,1 & 5,5 & 9,3 & 8,6 & 8,8 & 8,3 \\
Norwegia & 1,5 & 1,7 & 1,5 & 1,5 & 2,1 & 1,8 & 1,7 & 1,8 \\
Nowa Zelandia & 1,2 & 1,1 & 1,1 & 1,1 & 2,5 & 2,2 & 2,1 & 2,3 \\
Szwajcaria & 1,2 & 1,2 & 1,2 & 1,2 & 1,9 & 1,5 & 1,6 & 1,6 \\
UE-28 & 1,7 & 1,5 & 1,6 & 1,7 & 2,4 & 2,0 & 2,2 & 2,4 \\
USA & 1,8 & 1,5 & 1,6 & 1,7 & 1,9 & 1,8 & 1,8 & 2,1 \\
\hline
\end{tabular}

Źródło: opracowanie własne.

\section{Podsumowanie}

W latach 2008-2011 w państwach wysoko rozwiniętych wartości eksportu i importu dóbr pośrednich wahały się bardziej (w kategoriach bezwzględnych i względnych) niż wartości eksportu i importu dóbr finalnych i to niezależnie od przyjętej metody mierzenia handlu międzynarodowego. Dowodzi to występowania efektu Forrestera w handlu międzynarodowym oboma rodzajami dóbr w badanym okresie.

Ponadto, z analizy rzeczowej struktury handlu państw wysoko rozwiniętych wynika, że wartość handlu dobrami pośrednimi znacznie przewyższała wartość handlu dobrami finalnymi. To potwierdza tezy zarówno o rosnącym znaczeniu handlu dobrami pośrednimi, jak i o wielokrotnym liczeniu ich strumieni przepływających przez granice państw wraz z postępującym umiędzynarodowieniem produkcji. Zatem taki stan rzeczy świadczy o potrzebie nowego sposobu mierzenia handlu międzynarodowego, a mianowicie za pomocą wartości dodanej.

W celu uniknięcia nadmiernej liczby danych statystycznych w jednym opracowaniu, artykuł ten dotyczył tylko wybranych państw wysoko rozwiniętych, co naturalnie jest jego istotnym ograniczeniem. Kolejnym ograniczeniem przeprowadzonego badania empirycznego jest jego przedział czasowy. Wraz z pojawieniem się międzynarodowych tablic 
przepływów za rok 2012 oraz kolejne lata należy kontynuować badania nad międzynarodowym handlem dobrami pośrednimi i dobrami finalnymi. Co więcej, wartościowym uzupełnieniem tego artykułu może być badanie bilansów handlu dobrami finalnymi i dobrami pośrednimi.

\section{Literatura}

Altomonte C., Mauro F. D., Ottaviano G., Rungi A., Vicard V., 2012, Global value chains during the great trade collapse: a bullwhip effect?, "ECB Working Paper Series", no. 1412.

Czarny E., Folfas P., Śledziewska K., 2012, International Trade, Intermediaries, Final Goods and Economic Crisis, "Poznan University of Economics Review", no. 246.

Disney S. M., Towill D. R., 2003, On the bullwhip and inventory variance produced by an ordering policy, "International Journal of Management Science", no. 3.

Eichengreen B., 2009, Comments in Collapse in World Trade: A Symposium of Views, "The International Economics", Spring.

Ekonometria, 1996, M. Gruszczyński, M. Podgórska (red.), Oficyna Wydawnicza Szkoły Głównej Handlowej w Warszawie, Warszawa.

Folfas P., 2016, Handel miedsynarodony mierzony wartościq brutto oraz wartościq dodanq analiza porównawcza, Oficyna Wydawnicza Szkoły Głównej Handlowej w Warszawie, Warszawa.

Forrester J. W., 1961, Industrial Dynamics, MIT Press, Cambridge.

Kleinert J., 2000, Growing Trade in Intermediate Goods: Outsourcing, Global Sourcing or Increasing Importance of MNE Networks?, "Kiel Working Paper", no. 1006.

Liu B. J., 2011, Why World Exports Ares so Suspectible to the Economic Crisis - The Prevailing Export Overshooting Phenomenon, "NBER Working Paper", no. 16837.

Mason-Jones R., Towill D. R., 2000, Coping with Uncertainty: Reducing "Bullwhip” Behaviour in Global Supply Chains, "Supply Chain Forum", no. 1.

Measuring Trade in Value Added: An OECD-WTO joint initiative, Trade in Value Added (TiVA) - October 2015, http://stats.oecd.org/Index.aspx?DataSetCode=TIVA 2015_C1 (data wejścia: 17.07.2016).

Peng M. W., Ilinitch A. Y., 2001, Export Intermediary Firms: A Note on Export Development Research, "Journal of International Business Studies", no. 3.

Rauch J. E., Watson J., 2004, Network Intermediaries in International Trade, "Journal of Economics \& Management Strategy", no. 1.

Tempelmeier H., 2006, Inventory Management in Supply Networks - Problems, Models, Solutions, Norderstedt, Cambridge.

World Integrated Trade Solution, http://wits.worldbank.org/ (data wejścia: 17.07.2016).

Yi K. M., 2011, The Collapse of Trade: The Role of Vertical Specialization, [in:] The Collapse of Trade, Murky Protectionism and the Crisis. Recommendations for the G20, R. Baldwin (ed.), CEPR, London.

Zavacka V., 2012, The Bullwhip Effect and the Great Trade Collapse, "EBRD Working Paper", no. 148. 